https://doi.org/10.31743/sp.10619

\title{
GrZEgorz NANCKA
}

Prawo rzymskie w pracach Marcelego Chlamtacza Wydawnictwo Uniwersytetu ŚląsKiego, Katowice 2019, PP. 278

In 2019, the University of Silesia Publishing House printed a monograph by Grzegorz Nancka Ph.D. entitled Prawo rzymskie w pracach Marcelego Chlamtacza [eng. Roman Law in the Scholarly Output of the Marceli Chlamtacz] (pp. 278). I have worked on this position very seriously and with great interest for two reasons. Firstly, the author undertook a topic in the field of Roman law which fully coincides with my academic work, and secondly, the author linked Roman law to the former Jan Kazimierz University in Lviv which is a very important subject in the area of my interests (not only scientific ones). For these reasons, I always have great expectations for the new publications devoted to both, Roman law and the history of the Jan Kazimierz University in Lviv.

Prior to the reading of the reviewed monograph, I was curious how this work would present itself in comparison to the earlier publications devoted to Roman law and the history of teaching of this subject at the University of Lviv. Two books are worth mentioning here. The first one by Renata Wiaderna-Kuśnierz ${ }^{1}$ who focused on teaching Roman law at the University of Jan Kazimierz University in Lviv in 1918-1939, and the second by Bożena Czech-Jezierska ${ }^{2}$ who conducted research over several universities in the pre-war Poland, including the University of Lviv. It is also obligatory to mention here the works of Adam Redzik ${ }^{3}$ who devoted himself entirely to the study of the history of teaching at Lviv University. In addition to the above-mentioned monographs, many articles on this subject can be

1 R. Wiaderna-Kuśnierz, Prawo rzymskie na Uniwersytecie Jana Kazimierza we Lwowie w okresie międzywojennym (1918-1939), Toruń 2015.

2 B. Czech-Jezierska, Nauczanie prawa rzymskiego w Polsce w okresie międzywojennym (1918-1939), Lublin 2011.

3 Academia Militans. Uniwersytet Jana Kazimierza we Lwowie, ed. A. Redzik, Kraków 2015; A. Redzik, Wydziat Prawa Uniwersytetu Lwowskiego w latach 1939-1946, Lublin 2006. Cf. J. Draus, Uniwersytet Jana Kazimierza we Lwowie 1918-1946. Portret kresowej uczelni, Kraków 2007. 
found on the market. Incidentally, I must say with admiration that there is a tendency to undertake research focused on the history of teaching legal subjects at the pre-war Polish universities. Thanks to it, we can discover the profiles of specific scientists. ${ }^{4}$

In his work, Grzegorz Nancka, does not focus on the entire University or Faculty, but instead he presents one person - Marceli Chlamtacz (18651947), the Professor of Roman law at the Faculty of Law of the Jan Kazimierz University in Lviv. More specifically, the author focuses on the scientific achievements of M. Chlamtacz based on his works and publications in respect to Roman law. The choice of the research topic should be considered very accurate since the life and works of Professor M. Chlamtacz have not been widely known. In my opinion, G. Nancka shows a new way in the study of Roman law by presenting the outstanding Polish Roman law researchers and their works. As a consequence, it will allow to acknowledge the different styles of scientific work of such researchers, and will bring us closer to their publications. Thanks to this, such people and their achievements would not be forgotten.

The reviewed work consists of an introduction, four chapters, summary and attachments, such as a list of works by M. Chlamtacz and a list of sources and literature. The work has a total of 278 pages, which is sufficient. Due to the elegant presentation, quality of the print and the cover itself, the technical aspect of the book is worth noting. One may wonder why the author decided to showcase the watercolor by Stanisław Tondos (1854-1917) titled The Latin Cathedral in Lviv on the cover, and not to include more evident option, for example, the building of the Jan Kazimierz University in Lviv, or photographs of M. Chlamtacz himself. However, this outcome does not reduce the value of the reviewed work since it does not affect its content. The language of the work is very good and clear, so it is effortless for the book to bring closer the character of M. Chlamtacz and his achievements, not only to the Roman law experts but to all the people who are interested in the history of law, the history of Lviv and its University. From the stylistic and grammatical point of view, the work does not give rise to any objections.

In the first Chapter Biografia [eng. Biography] (pp. 17-79) G. Nancka introduces the character of Marceli Chlamtacz. However, the author does not limit himself to presenting only M. Chlamatacz's scientific path.

4 For example, in addition to the above: M. Tarkowski, Wydziat Prawa i Nauk Społecznych Uniwersytetu Stefana Batorego w Wilnie w latach 1919-1939, Gdańsk 2015. 
It should be remembered that in his career M. Chlamatacz also performed many administrative functions at the University: he was a practicing lawyer and an active local government official who for almost ten years had been performing duties of the Deputy Mayor of Lviv and for a long time served as the city councillor. The author extremely scrupulously - if it was even possible due to the lack of sources - presented the figure of Professor M. Chlamtacz. What is important, the author did not limit himself to the technical reconstruction of the biography of $\mathrm{M}$. Chlamtacz by quoting sources, but tried to interpret and draw conclusions from these biographical sources. For example, he presented his own views of the reasons why in 1933 Professor M. Chlamtacz was not approved by the Ministry to become the Rector of the University. ${ }^{5}$ The reading of this first chapter may bring some insufficiency in respect to the period from September 1939 to January 1947, i.e. from the outbreak of war to the death of Professor M. Chlamtacz. Grzegorz Nancka in his book devotes only four pages to that period. In my opinion such a personality as Marceli Chlamtacz a professor, a councillor, a city's deputy mayor, a dean of the faculty, an elected (though not approved) rector, an active local government activist - surely was known as an object of a special interest of the occupational authorities, from both sides, German and Soviet. In spite of this insufficiency, I am aware that, if the author had indeed focused on examining such an accurate resume of M. Chlamtacz, he would have lost the purpose of his work, that is the presentation of Roman law in the works of Professor M. Chlamtacz and not the Professor himself. Hence, we cannot blame the author for that, but we can only politely encourage him to write an article about wartime and the post-war history of M. Chlamtacz. ${ }^{6}$

The following chapters of the monograph, i.e. the second: Prace $z$ zakresu prawa rzeczowego [eng. Works in the Field of Property Law] (pp. 79-141), third: Prace $z$ zakresu prawa zobowiazan [eng. Works in the Field of Contract Law] (pp. 141-205) and fourth: Prace krytyczne [eng. Critical Works] (pp. 205-243)

5 For more information, cf. p. 43 of the monograph.

6 Grzegorz Nancka, in his work on page 53, writes (citing R. Wiaderna-Kuśnierz) that there is no data from the Soviet security services concerning M. Chlamtacz. But it does not indicate whether he tried to find or examine such acts by himself. It should be remembered that R. Wiaderna-Kuśnierz in her monograph conducted research over all Roman law Professors from the University of Jan Kazimierz in Lviv from the years 1918-1939, and therefore her query regarding Professor M. Chlamtacz did not have to be so meticulous, because she had to keep the right proportions at work. 
contain a well-developed list of publications by Marceli Chlamtacz. In these chapters, G. Nancka not only describes the achievements of Professor M. Chlamtacz but he also presents the Professor's views on the individual institutions of Roman law very efficiently. All those chapters show in a very clear and understandable way the achievements of Professor M. Chlamtacz. Thanks to this, the reader can get to know, not only the scientific interests but also the opinions of M. Chlamtacz. What is important, G. Nancka sporadically quotes the Latin sources that Professor M. Chlamtacz worked on, showing at the same time how he understood them. This allows us to really get into the Professor's scientific workshop since the reader can follow his way of reasoning. Particularly noteworthy is the fact that G. Nancka also presents the reviews that evaluate the works of Professor M. Chlamtacz (e.g. reviews by A. Ohanowicz, B. Walaszek, F. Bossowski, Z. Lisowski and R. Longchamps de Bérier). Thanks to that we can also learn how Professor M. Chlamtacz and his works were regarded by his contemporary researchers. This allows for a truly scientific (critical) assessment of M. Chlamtacz's output. This is a huge advantage of G. Nancka's monograph, and I believe that in such publications, where a specific researcher and his achievements will be described, the reviews of such works made by contemporary reviewers should also be presented. I believe that this ought to be a mandatory element in every major publication devoted to a selected scientist and his works, because it truly gives a full look at his scientific profile and work.

At the end of the work we can find the Summary, the chronologically arranged List of Works by Marceli Chlamtacz grouped according to the topics, and a List of Sources and Literature. Analyzing the bibliography, one question comes to mind: why G. Nancka does not reach for the Ukrainian literature? Despite some historical differences and mutual grievances, we must not forget that since 1944 the former Jan Kazimierz University has been functioning under the name the Ivan Franko National University of Lviv (ЛьВівський національний університет імені Івана Франка) and research on the history of the University and the former professors is often conducted there. ${ }^{7}$

7 As an example, I can indicate: В. Кахнич, Юридична освіта і наука у Львівському університеті (1661-1939), Львів 2016, рр. 319; Юридичний факультет. Львівський начіональний університет імені Івана Франка. 355 років (за заг. ред. В.М. Бурдіна, В.Т. Нора, I.Й. Бойка), Львів 2016, pp. 288; ENCYCLOPEDIA. Львівський національний університет імені Івана Франка. У 2 т., Львів 2011, рр. 1462. 
In conclusion, I am pleased to say that Grzegorz Nancka's work Prawo rzymskie w pracach Marcelego Chlamtacza is a very well-prepared monograph that will certainly have an important place among publications on Roman law and the history of teaching this subject at the University of Lviv. The author described a very important scientist and, at the same time, a local activist who played a significant role in the history of Lviv and its University. It is regrettable that Professor M. Chlamtacz has not been widely known in Poland so far, but thanks to G. Nancka's work everyone will have the chance to discover Professor M. Chlamtacz and his scientific achievements. Potius sero quam numquam!

reviewer Wojciech J. Kosior*

* Ph.D., LL.M., Assistant Professor, University of Rzeszów; e-mail: wjkosior@ur.edu.pl; ORCID ID: https:/ / orcid.org/0000-0002-4710-4523. 
